Mitchell, P. \& Moyle, J. (1951). J. gen. Microbiol. 5, 421-438.

\title{
Relationships between Cell Growth, Surface Properties and Nucleic Acid Production in Normal and Penicillin- Treated Micrococcus pyogenes
}

\author{
By P. MITCHELL AND JENNIFER MOYLE \\ Department of Biochemistry, University of Cambridge
}

\begin{abstract}
SUMMARY: The time course of the changes in the percentages by weight of ribonucleic acid, deoxyribonucleic acid and nucleic acid fragment (\%RNA, \%DNA and \% Nt respectively) and of their absolute rates of synthesis in a strain of Micrococcus pyogenes var. aureus (Staphylococcus aureus) has been studied throughout a complete normal growth cycle and compared with the changes which occur when penicillin $\mathbf{G}$ is added to the culture in the late logarithmic phase of growth. In normal cultures, the rate of cell growth (as dry weight) appears to be controlled by the $\%$ RNA, while the \%Nt varies inversely with the rate of synthesis of RNA, the Nt/(RNA + DNA) weight ratio being poised at about $0 \cdot 1$ during rapid growth. The rate of synthesis of DNA and the \%DNA, on the other hand, are related to the size of the cells in such a way as to maintain the weight of DNA per cell constant. The presence of $1 \mu \mathrm{g}$. of penicillin $/ \mathrm{ml}$. of culture at a cell dry-weight concentration of $200 \mu \mathrm{g} . / \mathrm{ml}$. causes an accumulation of free nucleotide + nucleoside and a depletion of free purine, and a change of the $\mathrm{Nt} /(\mathrm{RNA}+\mathrm{DNA})$ ratio from $c .0 \cdot 1$ to $c .0 \cdot 2$. The absolute rate of RNA synthesis is decreased more than that of DNA, but initially both \%RNA and \%DNA increase because of the inhibition of synthesis of some unidentified component which contributes significantly to the cell dry weight. The synthesis of an unidentified phosphate ester (XP) is also inhibited at an early stage in the penicillin-treated cultures. At the same time as the chemical changes, there are changes in the surfaces of the penicillin-treated cells, shown by their lightscattering properties and suspension stability. An attempt has been made to integrate the new observations into the general picture of penicillin action.
\end{abstract}

In the search for an explanation of the mode of action of penicillin upon sensitive organisms there has been a tendency to seek for a key reaction which may be considered to be the cause of toxicity. This attitude presupposes that the pathological symptoms exhibited by penicillin-treated cells represent the later stages in a sequence of events initiated by the key reaction. If the initiating step were known, the subsequent changes might be deduced as the dependent systems were discovered; but we are, in the reverse situation, attempting to guess the nature of the initiating reaction from the comparatively gross changes which follow it. Much is to be gained by a knowledge of the initiating step, but there is some danger that the importance of this step as the key to the subsequent changes may obscure the fact that each event leading from the initial contact with penicillin to the final loss of viability of the organism is equally instrumental in bringing about the lethal effect and is consequently of equal relevance to the description of the toxic process. The likelihood of success in identifying the salient features of the toxic process would seem to depend upon the study of a broad range of physiological indices, and upon our ability to trace back the observed changes to the earliest possible moment.

The observations of Cooper \& Rowley (1949) and of Maass \& Johnson (1949) 
on the uptake of isotope-tagged penicillin by penicillin-sensitive organisms indicate that the first of the sequence of events is the spontaneous combination of the penicillin with one or more cell components. If the evidence of Krampitz \& Werkman (1947) and of Gros \& Machboeuf (1948) for the inhibitory effect of high concentrations of penicillin on thick washed-cell suspensions is applicable to more dilute systems, one of the cell components with which the penicillin combines is presumably associated with the normal functioning of the nucleotide dissimilation systems. In resting or respiring non-growing cells the disturbances caused are comparatively slight and do not set in motion the changes leading to the lethal effects. When growth occurs in the presence of penicillin, however, the lethal changes occur in proportion to the amount of growth (Lee, Foley \& Epstein, 1944).

One consequence of growth in bactericidal concentrations of penicillin is damage to the mechanism responsible for the accumulation of glutamic acid in Gram-positive organisms, and it has been suggested that the starvation of the cells of glutamic acid which follows might be sufficient to account for the bactericidal action (Gale \& Taylor, 1947; Gale \& Rodwell, 1949): a thesis which, if true, would make the loss of the capacity for accumulating glutamic acid one of the last stages in the lethal action of penicillin. The component with which the penicillin initially combines is unlikely to play any direct part in the operation of the glutamic acid accumulation system, because penicillin does not affect this system in resting cells. There must, at all events, be one or more intermediate steps. It seemed possible that a study of the changes in nucleic acid synthesis in relation to cell growth in normal and penicillin-containing media might yield useful information with which to integrate our view of the course of events. A preliminary report of part of this work has been published (Mitchell, 1949a). A more detailed description has also been given (Mitchell, $1950 b)$.

\section{Cultural conditions}

\section{METHODS}

The organism selected for study, the strain Duncan of $M$. pyogenes var. aureus (Staphylococcus aureus), was grown in a casein digest medium containing $1 \%$ glucose and $0.1 \%$ Marmite. The effect of penicillin (crystalline penicillin G of Glaxo Laboratories) on the growth of the culture was observed at a concentration of $1 \mu \mathrm{g} . / \mathrm{ml}$., equivalent to $c .50 \mu \mathrm{g}$. of penicillin $/ \mathrm{mg}$. cell dry weight. The cultures were incubated at $25^{\circ}$ in order to slow the biological processes involved and to allow greater separation of the successive stages in the action of the penicillin than is possible at higher temperatures. The rotated culture method of Mitchell (1949b) was employed to give reproducible and favourable growth conditions.

\section{Measurement of dry weight}

In the present work, the weight of the cells after three rapid centrifugal washings in distilled water and drying to constant weight at $105^{\circ}$ was chosen to represent the total cell material in a given volume of culture, and the rate of dry-weight increase thus determined is described as the cell growth rate. 
The technical difficulty of washing a large volume of cells rapidly and without loss was found to be too great to allow accurate measurement of the dryweight concentrations of the low cell populations in the lag and logarithmic phases of growth, especially in the penicillin-treated cultures (see below). The dry-weight concentration of the cells was therefore estimated turbidimetrically in the culture medium at a wavelength of $700 \mathrm{~m} \mu$. with the Beckman Model DU spectrophotometer, using cuvettes giving a light path of $1 \mathrm{~cm}$. and diluting the suspensions appropriately with water to give extinctions not greater than 0.200. The expression $\log _{10} I_{0} / I=k_{\lambda} \cdot m / \lambda$ was used to relate the extinction $\left(\log _{10} I_{0} / I\right)$ to the dry-weight concentration $m$ in $\mu \mathrm{g} . / \mathrm{ml}$. at the wavelength $\lambda$ in $\mathrm{m} \mu ., k_{\lambda}$ being called the scattering coefficient.

During normal growth the value of $k_{700}$ varies within limits of $\pm 10 \%$ about a mean value of 0.90 (Mitchell, $1950 \mathrm{a}$ ). It was anticipated, however, that the pronounced cytological disturbances which occur during growth of $M$. pyogenes in the presence of penicillin might cause a wider variation of $k_{700}$ than that which occurs normally. Turbidimetric estimations of the dry-weight concentration of a penicillin-treated culture were therefore checked by gravimetric determinations of $k_{700}$ on the corresponding samples of cells washed with distilled water, with results similar to those shown in Fig. 8. The value of $k_{700}$ for the penicillintreated cells rises sharply after a delay of about $30 \mathrm{~min}$., reaching a final value about $70 \%$ above the normal and thus largely invalidating the uncorrected dry-weight determinations. It was therefore considered to be essential to make a gravimetric determination of $k_{700}$ for every turbidimetric dry-weight estimation in the penicillin-treated cultures.

\section{Estimation of nucleic acids and 'free nucleotide'}

The percentage by weight of 'total nucleotide' ( $\%$ NA) was estimated by the direct spectrophotometric method of Mitchell $(1950 \mathrm{a})$, with the addition of a refinement described later. The total purine-pyrimidine compounds extractable from the cells in cold trichloroacetic acid were determined spectrophotometrically and expressed as a percentage by weight of 'free nucleotide' $(\% \mathrm{Nt})$, assuming a specific extinction coefficient of 20 as for the 'total nucleotide'. The percentages by weight of deoxyribonucleic acid (\%DNA) and of so-called ribonucleic acid were estimated by an adaptation (Stephenson \& Moyle, 1949) of the phosphate method of Schmidt \& Thannhauser (1945). The percentages by weight of so-called ribonucleic acid obtained by the above method do not, in fact, represent the weight of ribonucleic acid (RNA) in the cells (Mitchell, 1950a; Mitchell \& Moyle, 1950). The measurements include a large proportion (often $30 \%$ or more) of phosphate in excess of that belonging to nucleotide units of RNA and they have therefore been called $\%(\mathbf{R N A}+\mathbf{X P})$. The most reliable RNA values may be obtained from the difference \% NA $\%(\mathbf{N t}+\mathbf{D N A})$.

\section{General experimental procedure}

Two litres of medium, stirred and aerated at $25^{\circ}$ in a rotated 5 l. flask was sown with $100 \mathrm{ml}$. of inoculum in the stationary phase of growth. Samples were withdrawn, beginning with a volume of $200 \mathrm{ml}$. and diminishing as the 
dry-weight concentration of the culture increased so as to keep the dry weight of each sample at about $30 \mathrm{mg}$. From each sample, $5 \mathrm{ml}$. was taken immediately for estimation of the extinction at $700 \mathrm{~m} \mu$. The remainder was centrifugally washed three times with distilled water without precautions as to loss and made up to a volume of just over $16 \mathrm{ml}$. Of this, $1 \mathrm{ml}$. was diluted to $100 \mathrm{ml}$. for spectrophotometric estimation of $\% \mathrm{NA}$ (Mitchell, 1950 a) and estimation of the extinction at $700 \mathrm{~m} \mu . ; 5 \mathrm{ml}$. was dried to constant weight at $105^{\circ}$ to give the dry-weight figure for the \%DNA and \%(RNA + XP) estimations and to obtain the value of $k_{\text {700 }}$ by which the culture density at the time of withdrawing the sample could be determined; $10 \mathrm{ml}$. was pipetted into $2 \mathrm{ml}$. of $30 \%$ trichloroacetic acid and kept at $0^{\circ}$ for $30 \mathrm{~min}$. to extract the 'free nucleotide' which was estimated by the extinction at $260 \mathrm{~m} \mu$. after diluting $1: 5$ with distilled water. The trichloroacetic acid-extracted cells were washed with distilled water and dissolved in $1 \mathrm{ml}$. of $\mathrm{N}$ sodium hydroxide by incubation at $35^{\circ}$ for $15 \mathrm{hr}$. After neutralizing the solution with $1 \mathrm{ml}$. of $\mathrm{N}$ hydrochloric acid, the DNA was precipitated with $2 \mathrm{ml}$. of $10 \%$ trichloroacetic acid and separated by centrifuging. The depolymerized RNA + the XP contaminant was estimated by the phosphorus content, using the method of Fiske \& Subbarrow (1925), assuming $10 \cdot 6 \mathrm{mg}$. to contain $1 \mathrm{mg}$. of phosphorus. After washing with distilled water, the precipitate of DNA was dissolved in $1 \mathrm{ml}$. of $\mathrm{N}$ sodium hydroxide and estimated by the phosphorus content in the same way as the RNA + XP.

The penicillin was introduced into $2 \mathrm{l}$. cultures in $1 \mathrm{ml}$. of sterile medium, and initial samples were taken immediately before and immediately after adding the penicillin.

\section{RESULTS}

Typical results of observations on a normal and a penicillin-treated culture (chosen from three pairs of similar experiments the results of which did not differ from each other significantly) are given in Table 1. Reference to the figures for $k_{350} / k_{700}$ shows that in the penicillin-treated culture, the deviation of the scattering spectra from the inverse law would introduce a significant error in the evaluation of \% NA if this were done in the normal way (Mitchell, 1950a). A simple refinement was consequently introduced to allow for the change of the slope of the scattering spectrum in each cell sample. Following the accepted method of expressing the relationship between wavelength and extinction (e.g. LaMer, 1943), the scattering spectrum from 700 to $260 \mathrm{~m} \mu$. is assumed to obey a law of the form $\left(\log _{10} I_{0} / I\right)=k . m /(\lambda)^{n}$, the symbols having the same meaning as before. It follows that the correct value for the extinction due to scattering at $260 \mathrm{~m} \mu$. may be obtained in terms of that at 350 and $700 \mathrm{~m} \mu$. from the relationship $\left(\log _{10} I_{0} / I\right)_{260 \mathrm{sc} .}=\left(\log _{10} I_{0} / I\right)_{350} \times(350 / 260)^{n}$, where $2^{n}=2 k_{350} / k_{700}$. In order to facilitate the determination of $\left(\log _{10} I_{0} / I\right)_{260 \text { sc., a table of values of }}$ $(350 / 260)^{n}$ for the observed range of values of $k_{350} / k_{700}$ was drawn up (Table 2).

To compare the behaviour of the normal and penicillin-treated cultures, time 0 in the culture immediately before the addition of the penicillin is fitted on the time scale of the normal culture by means of the dry-weight concentration. Time 0 in the penicillin-treated culture of Table 1 is thus found to correspond to $5 \mathrm{hr}$. in the normal culture. 
Fig. 1 shows that in the normal culture the $\%$ NA varies with the rate of growth, as previously noted (Mitchell, 1950a). The presence of penicillin causes a transient rise in the $\% \mathrm{NA}$ followed by a fall which runs parallel to the fall in the rate of growth.

Table 1. The time course of the changes in the dry-weight concentration, $\% N A, \% N t$, $\% D N A, \%(R N A+X P), k_{350}$ and $k_{700}$ in normal and penicillin-treated cultures of Micrococcus pyogenes

\begin{tabular}{|c|c|c|c|c|c|c|c|c|c|c|c|c|c|c|c|}
\hline $\begin{array}{l}\text { Time } \\
\text { (hr.) }\end{array}$ & $\begin{array}{l}\text { ODc } \\
700\end{array}$ & DWk & DWg & $\begin{array}{l}\text { ODw } \\
700\end{array}$ & $\begin{array}{l}\text { ODw } \\
\mathbf{3 5 0}\end{array}$ & $\begin{array}{c}\text { ODw } \\
260\end{array}$ & $\begin{array}{l}\text { ODe } \\
260\end{array}$ & $k_{700}$ & $\frac{k_{350}}{k_{700}}$ & $\begin{array}{l}\text { ODs } \\
\mathbf{2 6 0}\end{array}$ & $\begin{array}{c}\text { ODa } \\
260\end{array}$ & $\begin{array}{r}\% \\
\text { NA }\end{array}$ & $\begin{array}{c}\% \\
\mathbf{N t}\end{array}$ & $\begin{array}{c}\% \\
\text { DNA }\end{array}$ & $\begin{array}{c}\% \\
(\mathbf{R N A}+\mathbf{X P}\end{array}$ \\
\hline \multicolumn{16}{|c|}{ Normal } \\
\hline $0 \cdot 0$ & 68 & 51 & $24 \cdot 0$ & 32 & 57 & 152 & 212 & 0.93 & 0.89 & 74 & 78 & $16 \cdot 3$ & 4.43 & $2 \cdot 11$ & 22.5 \\
\hline $2 \cdot 5$ & 99 & 72 & $24 \cdot 6$ & 34 & 59 & 169 & 161 & $0 \cdot 97$ & $0 \cdot 89$ & 76 & 93 & 18.9 & $3 \cdot 29$ & $\mathbf{2} \cdot \mathbf{3 8}$ & $25 \cdot 6$ \\
\hline 5.5 & 288 & 214 & $41 \cdot 6$ & 56 & 105 & 327 & 182 & 0.94 & $0 \cdot 94$ & 138 & 189 & $22 \cdot 7$ & $2 \cdot 18$ & $\mathbf{2 \cdot 3 5}$ & $30 \cdot 1$ \\
\hline $7 \cdot 5$ & 642 & 475 & $42 \cdot 2$ & 57 & 113 & 334 & 184 & 0.94 & 0.99 & 152 & 182 & $21 \cdot 6$ & $2 \cdot 18$ & $2 \cdot 65$ & $27 \cdot 9$ \\
\hline $10 \cdot 5$ & 1490 & 1220 & $44 \cdot 4$ & 54 & 111 & 337 & 215 & 0.85 & $1 \cdot 03$ & 152 & 185 & $20 \cdot 9$ & $2 \cdot 42$ & $\mathbf{3} \cdot 32$ & $24 \cdot 6$ \\
\hline $13 \cdot 5$ & 2995 & 2480 & $53 \cdot 0$ & 64 & 138 & 388 & 207 & $0 \cdot 84$ & $1 \cdot 08$ & 192 & 196 & 18.5 & 1.95 & 3.32 & $23 \cdot 8$ \\
\hline $16 \cdot 5$ & 4820 & 3660 & $62 \cdot 2$ & 82 & 174 & 449 & 202 & 0.92 & 1.06 & 241 & 208 & 16.7 & $1 \cdot 62$ & - & - \\
\hline $21 \cdot 5$ & 5270 & 3800 & $54 \cdot 0$ & 75 & 158 & 383 & 122 & 0.97 & $1 \cdot 05$ & 218 & 165 & $15 \cdot 3$ & $1 \cdot 13$ & $\mathbf{3 . 5 5}$ & $20 \cdot 9$ \\
\hline \multicolumn{16}{|c|}{ Penicillin-treated } \\
\hline $0 \cdot 0$ & 240 & 187 & $47 \cdot 6$ & 61 & 115 & 360 & 235 & 0.90 & 0.94 & 152 & 208 & $21 \cdot 9$ & $2 \cdot 47$ & $2 \cdot 44$ & $28 \cdot 4$ \\
\hline \multicolumn{16}{|c|}{ ( $1.8 \mathrm{mg}$. of penicillin $\mathrm{G}$ added to give $1 \mu \mathrm{g} . / \mathrm{ml}$. of culture) } \\
\hline $0 \cdot 0$ & 228 & 179 & $47 \cdot 0$ & 60 & 111 & 352 & 227 & 0.89 & 0.92 & 144 & 208 & $22 \cdot 1$ & $2 \cdot 42$ & $2 \cdot 32$ & $28 \cdot 5$ \\
\hline 0.5 & 280 & 217 & $32 \cdot 6$ & 42 & 75 & 258 & 230 & 0.90 & 0.89 & 97 & 161 & $24 \cdot 7$ & $3 \cdot 60$ & $2 \cdot 63$ & $28 \cdot 2$ \\
\hline 1.5 & 365 & 220 & $37 \cdot 4$ & 62 & 108 & 307 & 235 & $1 \cdot 16$ & 0.87 & 138 & 169 & $22 \cdot 6$ & $3 \cdot 14$ & $3 \cdot 02$ & $25 \cdot 2$ \\
\hline 4.0 & 688 & 365 & $45 \cdot 0$ & 85 & 138 & 340 & 267 & $1 \cdot 32$ & 0.81 & 170 & 170 & 18.9 & 2.97 & 3.01 & $20 \cdot 6$ \\
\hline $7 \cdot 0$ & 508 & 246 & $40 \cdot 2$ & 83 & 134 & 302 & 208 & $1 \cdot 44$ & 0.81 & 165 & 137 & $17 \cdot 1$ & $2 \cdot 58$ & 3.22 & 19.5 \\
\hline $12 \cdot 0$ & 364 & 192 & $28 \cdot 4$ & 54 & 89 & 198 & 143 & 1.33 & 0.82 & 110 & 88 & $15 \cdot 5$ & 2.51 & $3 \cdot 10$ & $18 \cdot 7$ \\
\hline
\end{tabular}

DWk is the dry-weight concentration in $\mu \mathrm{g}$. cells $/ \mathrm{ml}$. of culture calculated from ODc 700, the optical density $(1000 \times$ $\left.\log _{10} I_{0} / I\right)$ of the culture at $700 \mathrm{~m} \mu$., and the value of $k_{700}$. DWg is the weight in $\mu \mathrm{g}$. of the cells in $5 \mathrm{ml}$. of the washed suspension dried at $105^{\circ}$. The ODw 700, ODw 350 and ODw 260 values are the optical densities of the washed suspension diluted at 1:100, at 700, 350 and $260 \mathrm{~m} \mu$. ODe 260 is the optical density at $260 \mathrm{~m} \mu$. of the Nt of the washed suspension diluted 1:5. ODs 260 and ODa 260 are the optical densities at $260 \mathrm{~m} \mu$. corresponding to scattering and absorption respectively, calculated from ODw 350, ODw 260 and $k_{350} / k_{700}$ with the aid of Table 2. Other symbols as in text.

Table 2. The dependence of $(350 / 260)^{n}$ upon $k_{350} / k_{700}$

$\begin{array}{cc}k_{350} / k_{700} & (350 / 260)^{n} \\ 0 \cdot 80 & 1 \cdot 23 \\ 0.85 & 1 \cdot 26 \\ 0.90 & 1 \cdot 29 \\ 0.95 & 1 \cdot 32 \\ 1.00 & 1 \cdot 35 \\ 1 \cdot 05 & 1 \cdot 38 \\ 1 \cdot 10 & 1 \cdot 40 \\ 1 \cdot 15 & 1 \cdot 43 \\ 1 \cdot 20 & 1 \cdot 46 \\ 1.25 & 1 \cdot 49\end{array}$

The \% $\mathrm{Nt}$ of the normal culture, shown in Fig. 2, is high in the late lag phase and falls rapidly as logarithmic growth is established. The high value of $\% \mathrm{Nt}$ at the time of taking the first sample (time 0 ) was presumably preceded by a rapid rise during the period of $2 \cdot 5 \mathrm{hr}$. which elapsed between putting in the 
inoculum of cells in the stationary phase of growth and withdrawing the first sample. The addition of the penicillin to the culture causes an immediate and very marked rise in the $\% \mathrm{Nt}$ followed by a fall which is less pronounced than that which occurs during normal growth (Fig. 2).

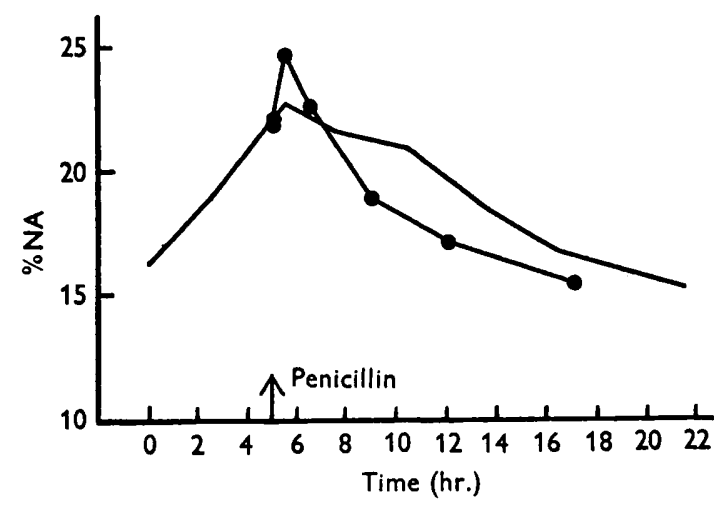

Fig. 1. The percentage by weight of 'total nucleotide' ( $\%$ NA) versus time in a normal culture (-), and in a culture containing $1 \mu \mathrm{g}$. penicillin G/ml. (-๑-).

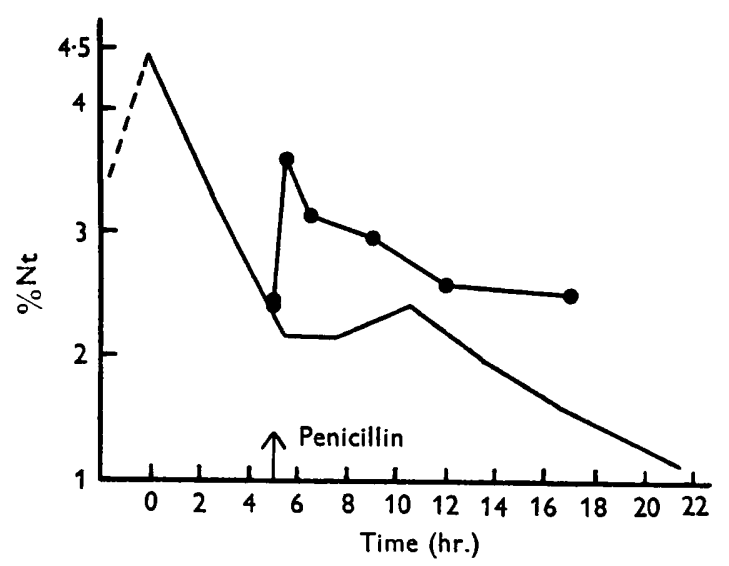

Fig. 2. The percentage by weight of 'free nucleotide' $(\% \mathrm{Nt})$ versus time in a normal culture (-), and in a culture containing $1 \mu \mathrm{g}$. penicillin $\mathrm{G} / \mathrm{ml}$.

Most of the rise in $\% \mathrm{NA}$ may be attributed to the rise in $\% \mathrm{Nt}$ as shown in Fig. 3 by the plot of $\%(N A-N t)$ which is equivalent to $\%($ RNA + DNA).

The balance between the weight of 'free nucleotide' $(\mathrm{Nt})$ and the weight of total nucleic acid (NA-Nt) is plotted in Fig. 4. In the normal culture, the $\mathbf{N t} /(\mathbf{N A}-\mathbf{N t})$ balance favours a high concentration of $\mathbf{N t}$ during the lag phase, but settles down in the logarithmic phase to a value which remains fairly steady throughout the subsequent growth of the culture. The presence of the penicillin causes the balance to swing rapidly in the direction of 'free nucleotide', an almost steady value of $\mathrm{Nt} /(\mathrm{NA}-\mathbf{N t})$ being attained after only $30 \mathrm{~min}$. growth in the penicillin-containing medium. 
The \%DNA, plotted in Fig. 5, rises during most of the growth period during which observations were made on the normal culture. This rise is presumably preceded by an equivalent fall during the early lag phase of growth. The presence of penicillin causes an immediate increase in the \%DNA towards the same value as that which is ultimately attained in the normal stationary phase of growth.

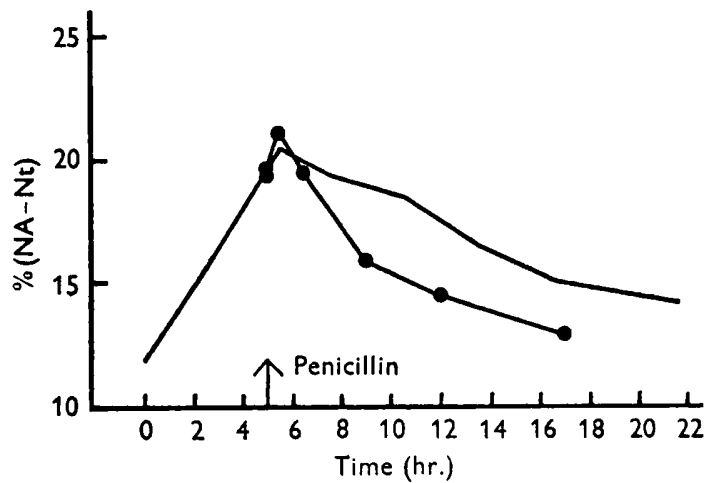

Fig. 3. The percentage by weight of total nucleic acid \% (NA-Nt) versus time in a normal

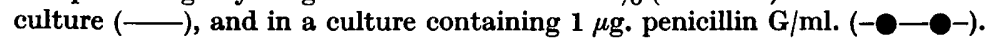

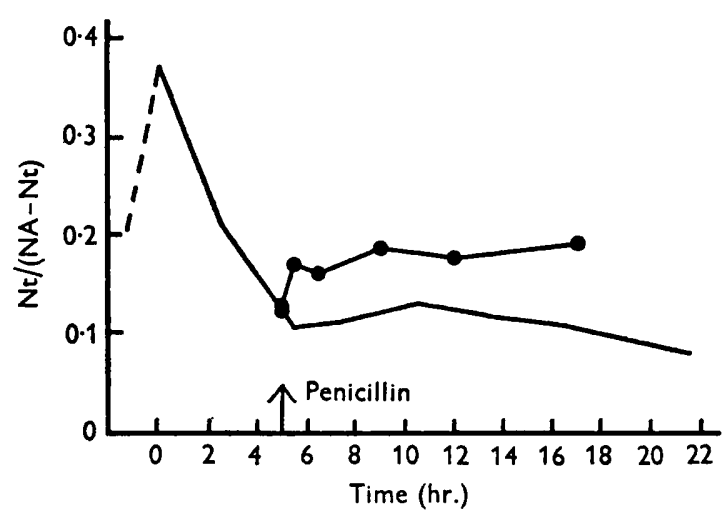

Fig. 4. The weight ratio of 'free nucleotide' to total nucleic acid $[\mathrm{Nt} /(\mathrm{NA}-\mathrm{Nt})]$ versus time in a normal culture (-), and in a culture containing $1 \mu \mathrm{g}$. penicillin $\mathrm{G} / \mathrm{ml}$. (-0-0).

A change in the percentage by weight of a given cell component may be caused either by a change in its rate of synthesis or by a change in the rates of synthesis of other cell components which contribute to the dry weight of the cells. Consequently, the changes in the percentages by weight of the components described above must not be interpreted as necessarily indicating corresponding changes in the rates of synthesis of these components. The changes in the net rates of synthesis are given by the rates of change of the total concentrations in the culture.

Fig. 6 shows the normal cell growth curve and the curves for growth of total nucleic acid and of DNA. During normal growth, in the period preceding the 
maximum rate of cell growth, the rate of reproduction of total nucleic acid is greater than that of cell dry weight, while in the period following the maximal rate of cell growth, it is less: thus accounting for the maximum in the percentage by weight of total nucleic acid near the centre of the logarithmic phase

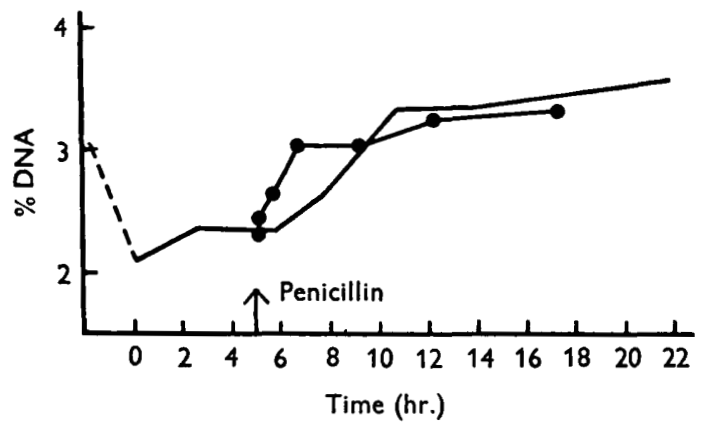

Fig. 5. The percentage by weight of deoxyribonucleic acid (\% DNA) versus time in a normal culture $(\longrightarrow$, and in a culture containing $1 \mu \mathrm{g}$. penicillin $\mathrm{G} / \mathrm{ml}$.

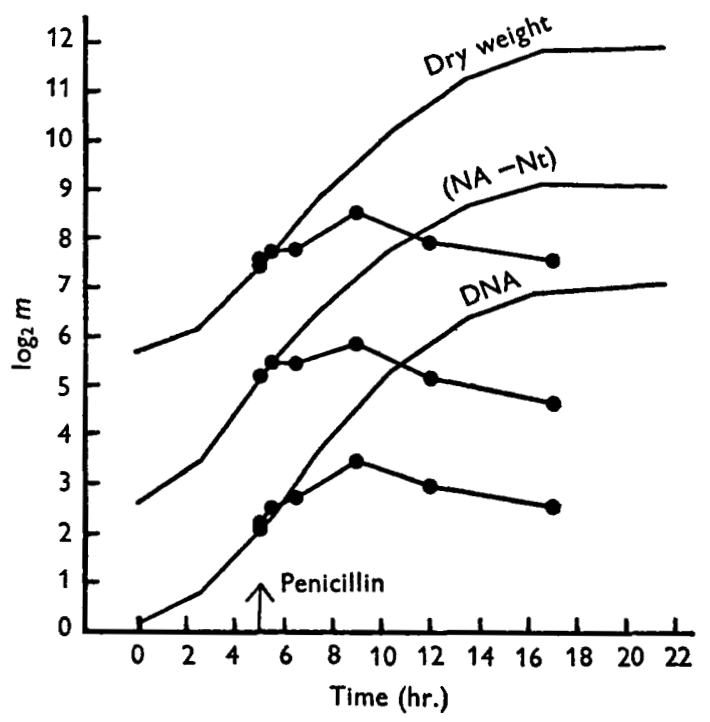

Fig. 6. The rates of reproduction (expressed as $\log _{2}$ of the concentration in $\mu \mathrm{g} . / \mathrm{ml}$.) of cell dry weight, total nucleic acid (NA - Nt) and deoxyribonucleic acid (DNA) in a normal culture (-), and in a culture containing $1 \mu \mathrm{g}$. penicillin $\mathrm{G} / \mathrm{ml}$. (-०-).

of growth. On the other hand, the rate of reproduction of DNA is slightly greater than that of cell dry weight throughout most of the growth period: thus accounting for the increase in the \% DNA.

After the addition of penicillin to the culture, cell growth is more or less logarithmic for the first $4 \mathrm{hr}$., but the apparent mean generation time is much extended. During the first $\mathbf{3 0}$ min., there is little or no decrease in the rate of synthesis of total nucleic acid, and little or no decrease in the rate of 
synthesis of DNA, whereas there is a significant fall in the rate of cell dryweight production. Consequently, the small initial rises in the $\%(\mathrm{NA}-\mathrm{Nt})$ and $\%$ DNA after the addition of the penicillin to the culture may be attributed, not to a stimulation of production of these components, but to an inhibition of synthesis of some other component which contributes significantly to the cell dry weight. After growth has continued for $90 \mathrm{~min}$. in the presence of the penicillin, the cell growth rate is decreased to about $\mathbf{0 . 2}$ of its initial value, the net rate of synthesis of total nucleic acid is decreased slightly more, but the net rate of DNA synthesis is decreased only to $0 \cdot 6$ of the initial value : thus accounting for the fall in the percentage by weight of total nucleic acid and the continued rise in the $\%$ DNA at this stage.

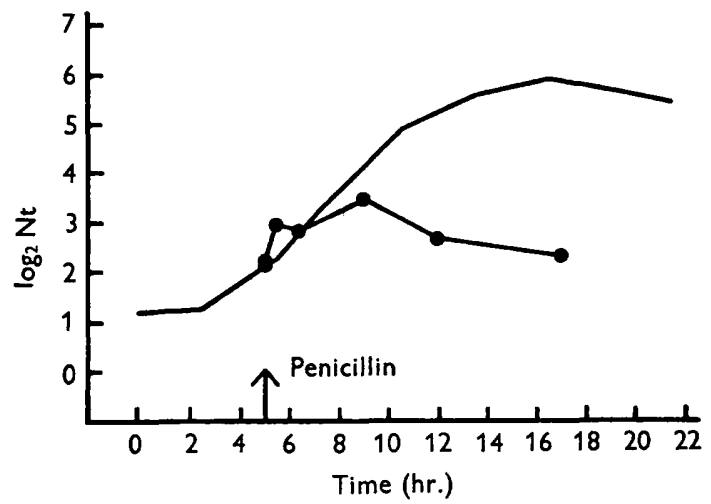

Fig. 7. The rate of reproduction (expressed as $\log _{2}$ of the concentration in $\mu \mathrm{g} . / \mathrm{ml}$.) of 'free nucleotide' ( $\mathrm{Nt})$ in a normal culture $(\stackrel{\mathrm{G}}{-})$, and in a culture containing $1 \mu \mathrm{g}$. penicillin G/ml. (-O-O).

The curve of Fig. 7 shows that the growth of $\mathrm{Nt}$ in the normal culture is less rapid than that of cell growth during the period of observation, in conformity with the fall in $\% \mathrm{Nt}$. It is evident that, unlike the other cases, the rise in $\% \mathrm{Nt}$ which occurs immediately after the addition of the penicillin to the culture is due to an absolute stimulation of $\mathrm{Nt}$ production.

The values of $k_{700}$ of Fig. 8 show that for the first $30 \mathrm{~min}$. after the addition of the penicillin, the value of $k_{\text {zo0 }}$ remains unchanged, but it subsequently rises precipitately. The rise in the scattering coefficient of the penicillin-treated cells is an index of changes which increase the proportion of the incident light reflected by the cell surfaces per unit dry weight. These changes might be due either to an extension of the effective reflecting surface area of the cells per unit dry weight, or to an increase in reflecting power of the surface, or to a combination of both types of change. It has been pointed out that the steepness of the scattering spectrum represented by $k_{350} / k_{700}$ is, on the other hand, almost independent of wide changes in the reflecting power of the cell surfaces, but that it is a sensitive index of particle size (Mitchell, 1950 a). The variation of size during growth of the normal cells and of cells treated with penicillin is illustrated in Fig. 9. The normal cells become progressively smaller throughout 
the period of growth under observation, a corresponding increase in size presumably occurring during the early lag phase. Microscopic observations on the normal cells showed that the mean diameter changed progressively from about $0.8 \mu$. in the early $\log$ phase to about $0.65 \mu$. in the stationary phase of

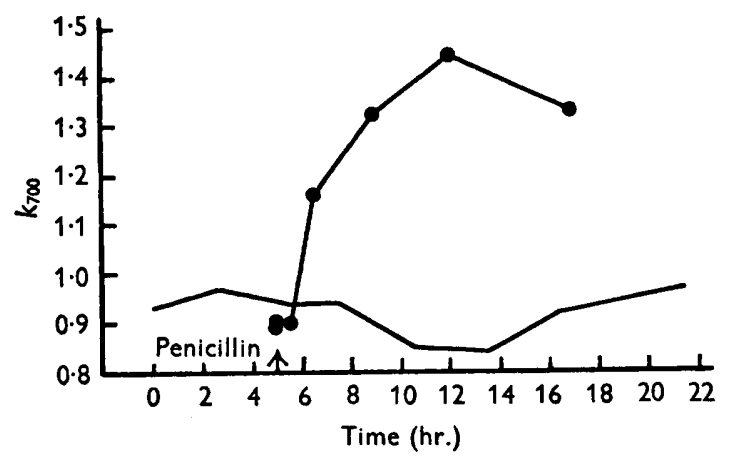

Fig. 8. The light scattering power of the cells given by the index $k_{700}$ versus time in a normal culture (-), and in a culture containing $1 \mu \mathrm{g}$. penicillin $\mathrm{G} / \mathrm{ml}$. (-๑-).

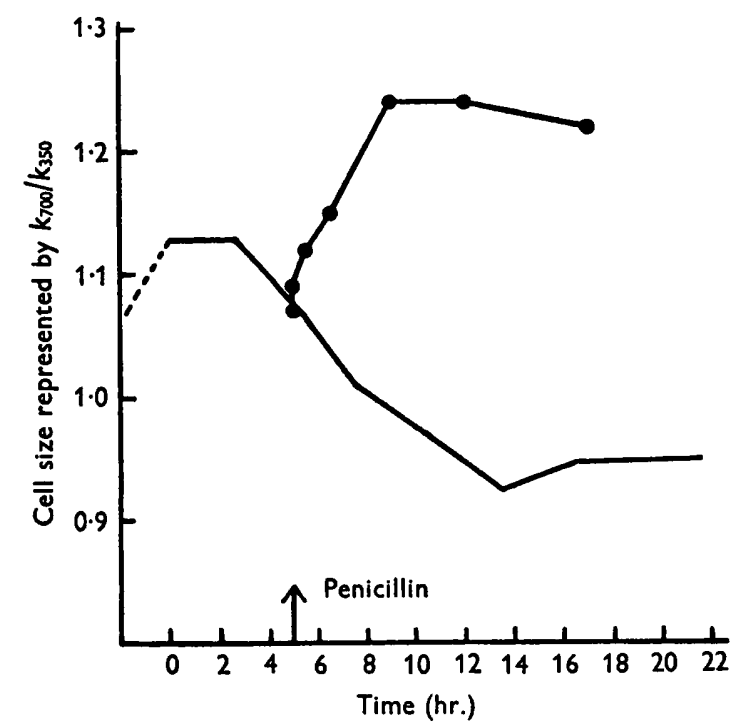

Fig. 9. Cell size versus time in a normal culture (-), and in a culture containing $1 \mu \mathrm{g}$. penicillin $\mathrm{G} / \mathrm{ml}$.

growth. Fig. 9 shows that the cells begin to swell immediately after contact with the penicillin. It was noted that the swelling and increase in the scattering coefficient were accompanied by a change in the dispersibility of the washed cell suspensions, the centrifuged pads of cells exhibiting a remarkable 'stickiness'.

In order to examine more closely the changes in the $\% \mathrm{Nt}$ during the first hour of growth in the presence of the penicillin, an experiment similar to that 
of Table 1 was devised in which the samples were taken immediately before and after the addition of the penicillin and thereafter at intervals of $10 \mathrm{~min}$. The absorption spectra of the samples were determined in $1 \%$ trichloroacetic acid at the same concentration as that previously used for the determination

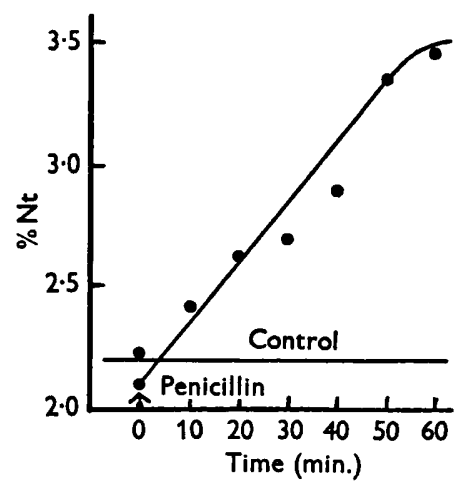

Fig. 10. The early changes in the percentage by weight of 'free nucleotide' ( $\% \mathrm{Nt})$ in a culture containing $1 \mu \mathrm{g}$. penicillin G/ml. (-- -) compared with a normal control (-).

of the extinction of the $\mathrm{Nt}$ fraction at $260 \mathrm{~m} \mu$., and the dry weights of the cells were measured directly as before. Fig. 10 shows that the $\% \mathrm{Nt}$ rises almost linearly from the moment at which the penicillin makes contact with the cells, reaching a value more than $50 \%$ greater than that of the control at the end of the $1 \mathrm{hr}$. period of the experiment. At the same time there is a movement of the absorption maximum of the $\mathrm{Nt}$ towards the red end of the spectrum (Table 3 ). The movement of the spectrum suggested a change in the balance between free purine and pyrimidine, and the corresponding nucleotide and nucleoside in

Table 3. The effect of $1 \mu \mathrm{g}$. penicillin $\mathrm{G} / \mathrm{ml}$. on the absorption spectrum of the $N t$ fraction of growing Micrococcus pyogenes var. aureus

Time of growth in penicillin-containing medium (min.)

\begin{tabular}{lllllllll}
$\mathbf{m} \mu$. & $\mathbf{N}_{\mathbf{0}}$ & $\mathbf{P}_{\mathbf{0}}$ & \multicolumn{1}{l}{10} & $\mathbf{2 0}$ & $\mathbf{3 0}$ & \multicolumn{1}{c}{40} & \multicolumn{1}{c}{50} & \multicolumn{1}{c}{$\mathbf{6 0}$} \\
$\mathbf{2 5 0}$ & $\mathbf{3 3 6}$ & $\mathbf{3 4 9}$ & $\mathbf{3 7 6}$ & $\mathbf{4 0 6}$ & $\mathbf{4 0 7}$ & $\mathbf{4 3 6}$ & $\mathbf{5 0 4}$ & $\mathbf{5 1 7}$ \\
$\mathbf{2 5 5}$ & $\mathbf{5 9 8}$ & $\mathbf{4 2 2}$ & $\mathbf{4 6 4}$ & $\mathbf{4 9 2}$ & $\mathbf{5 0 3}$ & $\mathbf{5 3 5}$ & $\mathbf{6 1 9}$ & $\mathbf{6 4 1}$ \\
$\mathbf{2 5 8}$ & $\mathbf{4 1 4}$ & $\mathbf{4 4 7}$ & $\mathbf{4 7 5}$ & $\mathbf{5 1 9}$ & $\mathbf{5 3 2}$ & $\mathbf{5 7 1}$ & $\mathbf{6 6 0}$ & $\mathbf{6 8 0}$ \\
$\mathbf{2 6 0}$ & $\mathbf{4 1 8}$ & $\mathbf{4 4 5}$ & $\mathbf{4 8 3}$ & $\mathbf{5 2 7}$ & $\mathbf{5 4 0}$ & $\mathbf{5 8 1}$ & $\mathbf{6 6 9}$ & $\mathbf{6 9 2}$ \\
$\mathbf{2 6 2}$ & $\mathbf{4 1 7}$ & $\mathbf{4 4 3}$ & $\mathbf{4 8 3}$ & $\mathbf{5 2 7}$ & $\mathbf{5 4 0}$ & $\mathbf{5 8 4}$ & $\mathbf{6 7 3}$ & $\mathbf{6 9 7}$ \\
$\mathbf{2 6 5}$ & $\mathbf{4 0 4}$ & $\mathbf{4 3 0}$ & $\mathbf{4 7 2}$ & $\mathbf{5 1 3}$ & $\mathbf{5 3 2}$ & $\mathbf{5 7 6}$ & $\mathbf{6 5 4}$ & $\mathbf{6 8 5}$ \\
$\mathbf{2 7 0}$ & $\mathbf{3 4 6}$ & $\mathbf{3 7 0}$ & $\mathbf{4 0 9}$ & 447 & $\mathbf{4 6 7}$ & $\mathbf{5 0 7}$ & $\mathbf{5 8 6}$ & $\mathbf{6 0 5}$ \\
$\mathbf{2 7 5}$ & $\mathbf{2 6 1}$ & $\mathbf{2 7 8}$ & $\mathbf{3 0 9}$ & $\mathbf{3 3 7}$ & $\mathbf{3 6 5}$ & $\mathbf{3 8 8}$ & $\mathbf{4 5 3}$ & $\mathbf{4 5 8}$ \\
$\mathbf{2 8 0}$ & $\mathbf{1 8 2}$ & $\mathbf{1 9 0}$ & $\mathbf{2 1 0}$ & $\mathbf{2 3 2}$ & $\mathbf{2 5 6}$ & $\mathbf{2 7 4}$ & $\mathbf{3 1 6}$ & $\mathbf{3 2 1}$ \\
$\mathbf{2 9 0}$ & $\mathbf{8 0}$ & $\mathbf{7 7}$ & $\mathbf{8 6}$ & $\mathbf{8 6}$ & $\mathbf{1 0 2}$ & $\mathbf{1 0 5}$ & 117 & 118 \\
$\mathbf{3 0 0}$ & $\mathbf{2 9}$ & $\mathbf{2 1}$ & $\mathbf{2 2}$ & $\mathbf{2 2}$ & $\mathbf{3 4}$ & $\mathbf{2 6}$ & $\mathbf{2 8}$ & $\mathbf{2 6}$
\end{tabular}

The body of the table contains the values of the optical density $\left(1000 \times \log _{2} I_{0} / I\right)$ in $1 \%$ trichloroacetic acid of the trichloroacetic acid extracts from $1 \mathrm{mg}$. dry weight of cells $/ \mathrm{ml}$. $\mathbf{N}_{0}$ and $\mathbf{P}_{0}$ are the samples taken immediately before and after adding the penicillin. Sample $\mathbf{P}_{0}$ may have continued growing during centrifuging for a maximum of $5 \mathrm{~min}$. 
the direction of increasing nucleotide + nucleoside concentration (Hotchkiss, 1948; Ploeser \& Loring, 1949). In order to examine this possibility, the $\mathrm{Nt}$ fraction of a normal culture of population density corresponding to a dryweight concentration of $650 \mu \mathrm{g} . / \mathrm{ml}$. and of the same culture after $30 \mathrm{~min}$. growth in the presence of $1 \mu \mathrm{g}$. penicillin $\mathrm{G} / \mathrm{ml}$. was separated into free purine, total purine and total pyrimidine fractions by the method of Kerr \& Seraidarian (1945). The absorption spectra of the fractions were determined. Although the extinction values of the free and total purine fractions from the normal and penicillin-treated cells were different, the shapes of the spectra were identical. It was consequently inferred that the changes of composition of $\mathrm{Nt}$ which give rise to the change of absorption spectrum in the penicillintreated cells is not due to a change in the relative proportions of the purine bases. On the other hand, growth in the penicillin-containing medium for $30 \mathrm{~min}$. caused the total purine to increase by a factor of $1 \cdot 19$, while the free purine decreased by a factor of 0.54 : thus showing a substantial accumulation of purine nucleotide + nucleoside. The absorption spectrum of the pyrimidine fraction also indicated a change in conformity with an accumulation of nucleotide + nucleoside in the penicillin-treated cells, the absorption maximum moving from 260 to $264 \mathrm{~m} \mu$. It was concluded that both the increase in the extinction and the change in the absorption spectrum of the whole $\mathrm{Nt}$ fraction of the penicillin-treated cells could be attributed to an accumulation of purine (and probably also pyrimidine) nucleotide + nucleoside.

In the computation of the net rates of synthesis of the cell components from data such as those of Table 1 , it was assumed that the $k_{700}$ value of the cells growing in the culture is unchanged by washing in distilled water. Because of the dubious validity of this assumption, and because there might have been a variable loss of dry weight during the washing operation, particularly in the penicillin-treated cells, it was not certain that the changes in the net rates of synthesis of NA and of the other components, computed from Table 1, were correct. It seemed advisable, therefore, to attempt to measure the $\% \mathrm{NA}$ and the volume concentration of NA direct in a growing culture so as to avoid the above uncertainties. The very strong ultraviolet light absorption of the medium made direct photometric measurements of NA impossible unless the medium were diluted at least $\mathbf{2 0}$ times with water. It was feared that dilution might cause disturbances which would mask the effects which it was intended to reveal; but it was found, on the contrary, that dilution caused a slowing of the toxic process and thus facilitated the observation of its progress.

A culture of $\boldsymbol{M}$. pyogenes was grown in $5 \mathrm{ml}$. of the normal medium at $35^{\circ}$ until the stationary phase was reached. The cells were centrifuged down and resuspended in $5.5 \mathrm{ml}$. of fresh sterile medium. Two 11 . conical flasks, each containing $50 \mathrm{ml}$. of sterile $0.2 \%$ glucose, were inoculated with $2.5 \mathrm{ml}$. of the suspension and held at $25^{\circ}$. After a lag phase of $2 \mathrm{hr}$., the NA content of $5 \mathrm{ml}$. samples was estimated by the direct spectrophotometric method against a control of similarly diluted medium. Immediately after each estimation, the cells of the sample were centrifuged down, and the absorption of the medium was determined against the same control. It was thus possible to obtain the 
value of the extinction at 350 and at $260 \mathrm{~m} \mu$. of the cells and medium. The light scattering at $350 \mathrm{~m} \mu$. was used in this instance to assess the dry-weight concentrations of the cultures, assuming $k_{350}=0.90$, and the NA content of the cells was estimated assuming $k_{350} / k_{700}=1$. The extinction coefficient of the nucleic acid of both cells and medium at $260 \mathrm{~m} \mu$. was assumed to be 20 as before.

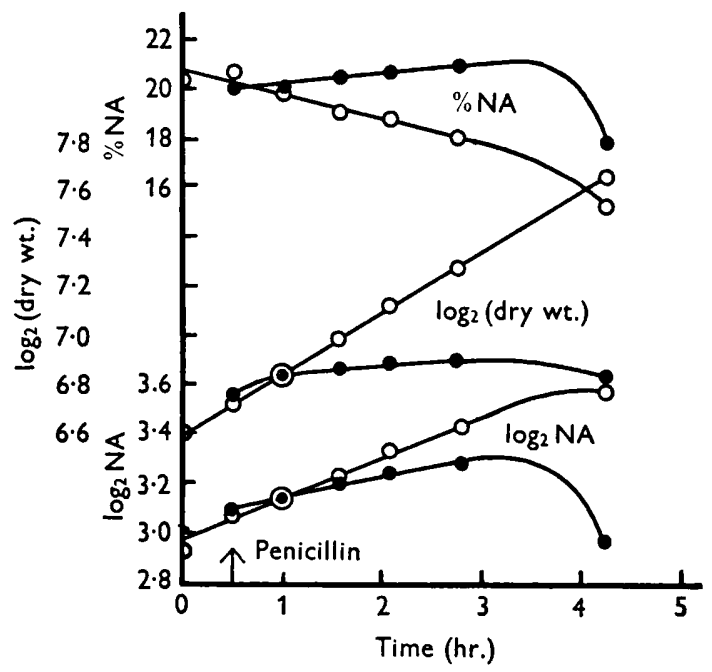

Fig. 11. The rates of reproduction (expressed as $\log _{2}$ of the concentrations in $\mu \mathrm{g} . / \mathrm{ml}$.) of 'total nucleotide' (NA) and cell dry weight and changes in the percentage by weight of 'total nucleotide' ( $\%$ NA) estimated direct in a normal culture (-O- - -), and in a culture containing $1 \mu \mathrm{g}$. penicillin $\mathrm{G} / \mathrm{ml}$. (-O-O-).

The point at which the penicillin (50 $\mu \mathrm{g}$. in $0 \cdot 1 \mathrm{ml}$. of distilled water) was put into one of the flasks is indicated in Fig. 11. During the period of growth represented in Fig. 11, the values of the extinction of the medium of both normal and penicillin-treated cultures showed that there was neither accumulation nor loss of purine-pyrimidine compounds in the medium until the time of taking the last sample, when a small increase in the purine-pyrimidine content of the medium was observed in the penicillin-treated culture. The changes in NA content described by Fig. 11 consequently represent purine-pyrimidine compounds synthesized or broken down by the cells, there being no net accumulation from the medium.

For the normal growth, the slope of $\log _{2} \mathrm{NA}$ is constant for more than $2 \mathrm{hr}$. but less than the slope of $\log _{2}$ (dry-weight concentration) which is also constant, and hence there is a linear decrease in the \% NA over this interval, from the high value of the rapidly growing cells of the inoculum towards a low value commensurate with the slow cell growth rate in the diluted medium.

Since it has been established that $k$ increases with time in penicillin-treated cultures, the slope of $\log _{2}$ (turbidimetric dry-weight concentration) assuming $k=0.90$ must be equal to, or greater than, the slope of $\log _{2}$ (corrected dry-weight concentration), and similarly, since $k_{350} / k_{700}$ decreases with time in penicillintreated cultures, the slope of $\log _{2} \mathrm{NA}$ assuming $k_{350} / k_{700}=1$ must be equal to or 
less than $\log _{2}$ (corrected NA). Evidently, therefore, in the penicillin-treated culture the rate of cell growth decreases more relative to that of NA reproduction and the \% NA rises more steeply than is indicated by the uncorrected values of Fig. 11. The mean generation time is more than $4 \mathrm{hr}$. for the normal culture in the diluted medium in place of $1.4 \mathrm{hr}$. in the undiluted medium, and the time taken for the \% NA to reach its maximum in the penicillin-treated culture is correspondingly extended by a factor of 3 or more. It is evident that the initial rise in the $\% \mathrm{NA}$ of the penicillin-treated cultures is due, not to a stimulation of the net rate of purine-pyrimidine production, but to an inhibition of production of some other cell component or components which contribute significantly to the dry weight. The conclusions drawn from the data of Table 1 are thus confirmed.

\section{DISCUSSION}

During the growth of normal cultures of $M$. pyogenes, the composition of the cells undergoes wide variation. The range of variation of 'total nucleotide' expressed by the index $\%$ NA between a value of about $13 \%$ in cultures in the early lag phase to about $25 \%$ at the period of most rapid growth is approximately the same as that reported by Malmgren \& Hedén (1947) on the basis of their microspectrophotometric studies. But, whereas they frequently observed two maxima in the quantity corresponding to \% NA in Gram-positive organisms, only one maximum was ever observed in the present work. Unlike the $\%$ NA, however, the 'free nucleotide', expressed by the index $\% \mathrm{Nt}$, shows two maxima, and it appears significant that both maxima occur during phases of rapid adjustment of the organisms to the nutrient conditions of the medium.

Malmgren \& Hedén (1947) made the interesting observation that in a number of bacteria the maximum rate of synthesis of 'total nucleotide' preceded the maximum rate of synthesis of cell substance (as dry weight). They suggested that the hypothesis of Caspersson (1947), that the synthesis of cell protein is preceded by, and is dependent upon, the production of ribonucleic acid, might apply to bacteria as to other organisms. Malmgren \& Hedén believed the hypothesis of Caspersson to be confirmed for the Gram-negative organisms which they studied, but there was doubt about the Gram-positive organisms because of the double maxima in the values corresponding to $\% \mathrm{NA}$. In the present studies it was noted that the slope of $\log _{2}(\mathrm{NA}-\mathrm{Nt})$ against time reaches its maximum in advance of that of $\log _{2}$ (dry-weight concentration), thus showing that total nucleic acid is reproduced more rapidly than cell dry weight (the larger proportion of which represents cell protein) during the phase of accelerated cell growth. Subtraction of the DNA from the total nucleic acid given by the index (NA-Nt) shows that it is the RNA synthesis which accelerates most during the phase of accelerated cell growth. The time of maximum percentage by weight of total nucleic acid (or of RNA) follows that of the maximum rate of nucleic acid reproduction by about $1 \mathrm{hr}$., so that, although the time of maximum rate of cell growth follows that of the maximum rate of nucleic acid synthesis, it occurs almost simultaneously with the period of maximum percentage by weight of nucleic acid. Thus, the rate of cell protein 
synthesis appears to be controlled by the percentage by weight of nucleic acid in the cells, while the rate of nucleic acid synthesis appears to be more directly determined by the nutritive properties of the medium than protein synthesisin accordance with the hypothesis of Caspersson (1947).

A similar interpretation may be placed upon the relationship between the percentage by weight of 'free nucleotide' or nucleic acid fragment $(\% \mathrm{Nt})$ and that of total nucleic acid. During the lag phase of growth, large amounts of $\mathrm{Nt}$ synthesized by the cells or taken up from the medium are accumulated within the cells. As this concentration is built up, the rate of reproduction of nucleic acid accelerates and the $\% \mathrm{Nt}$ then begins to fall. As the rate of reproduction of total nucleic acid rises towards its maximum, the ratio $\mathrm{Nt} /(\mathrm{NA}-\mathrm{Nt}$ ) falls to a fairly steady value near $0 \cdot 1$. Thus, there appears to be a balance between the weights of nucleic acid fragment and total nucleic acid, conditioned by the rate of accumulation of nucleic acid fragment relative to its rate of polymerization to form nucleic acid, the latter being dependent upon the synthesis of the appropriate enzyme proteins.

The observations on the slopes of the scattering spectra described here show the same changes in cell diameter during normal growth as those reported by Henrici (1923). The $\% \mathrm{Nt}$ runs parallel to the degree of swelling. The $\% \mathrm{DNA}$, on the other hand, is 1.7 times as great in the stationary phase of growth as in the late lag phase, while the cell volume changes by a factor of $(0 \cdot 65 / 0 \cdot 80)^{3}=0.54$ during the same period. Assuming the degree of hydration of the cells to remain constant, the weight of DNA per cell must have changed by a factor of only 0.92 ; or in other words, within the limits of experimental error the weight of DNA per cell remains constant, the amount per cell being about $10^{-15} \mathrm{~g}$.

When a bacterial culture grows without change of composition, the relative net rate of synthesis of each cell component must be proportional to the relative weight of the component in the cells. If all the net rates of synthesis were multiplied by the same factor, no change of composition would result and the survival of the cells would not be endangered. On the other hand, an environmental modification which induces a change in the relative net rate of synthesis of a particular cell component must subsequently lead to a corresponding change of cell composition. This change of composition may either result in the reversible establishment of a new steady condition in which the growth of the cells continues, or it may be such as to render the culture incapable of organized growth. The observations described here show how the changes in the nutritive properties of the medium occurring during normal growth give rise to a wide range of cell compositions between which a reversible movement is possible.

The presence of penicillin in growing cultures of $M$. pyogenes causes the immediate onset of changes in the net composition of the cells. The rapid shift in the ratio of nucleic acid fragment to total nucleic acid [Nt/(NA-Nt)] from its normal value near 0.1 to a new steady value near 0.2 is in conformity with the observations of Krampitz \& Werkman (1947) and of Gros \& Machboeuf $(1948,1949)$ on the inhibitory effect of penicillin on nucleotide dissimilation in washed cell suspensions. Since the increase in $\mathbf{N t} /(\mathbf{N A}-\mathbf{N t})$ is accompanied 
by a slight inhibition of total nucleic acid synthesis and a decrease in the free purine concentration, there is evidently not only a decrease in the net rate of conversion of nucleic acid fragments to nucleic acid but also a net inhibition of free purine production or accumulation.

The rapid initial rise in \% DNA, due to the relatively small inhibition of DNA synthesis, confirms the cytological observations of Tulasne \& Vendrely (1948) on the inhibition of the growth of a micrococcus in penicillin-containing medium and corroborates their view that 'penicillin interferes with multiplication by inhibition of cytoplasmic rather than nucleal divisions'.

The hypothesis, published by Gale (1948), that penicillin causes loss of the Gram-complex and inactivation of the glutamic acid accumulation system by inhibition of RNA synthesis is proved to be at least partially incorrect for the following reasons: (i) although there is an absolute inhibition of both RNA and DNA production in the penicillin-treated cultures, the percentages by weight of these components initially increase because there is a more pronounced inhibition of some unidentified cell component or components; (ii) doubt has been cast upon the validity of the magnesium ribonucleate Gram-complex theory of Henry \& Stacey (1946), by Boivin (1948), and by Mitchell \& Moyle (1950); (iii) the intensity of the Gram-staining of the micrococci (Dufrenoy \& Pratt, 1947) and their ability to accumulate glutamic acid (Gale \& Taylor, 1947). decrease fairly rapidly as growth proceeds in the presence of penicillin, although the level of the \% RNA does not fall below that of older cells in which Gramstaining and glutamic acid accumulation are normal. According to Gale (1948), the ratio of DNA to RNA undergoes a large increase in the penicillin-treated cells of $M$. pyogenes. This ratio does undergo a small initial increase because the inhibition of DNA synthesis is somewhat less than that of RNA; but it will be noted that the decrease in the true DNA/RNA ratio is much less than that in the ratio DNA/(RNA + XP), erroneously taken to represent DNA/RNA by Gale. The difference $\%[\mathbf{R N A}+\mathbf{X P}]-[\% \mathbf{N A}-\%(\mathbf{N t}+\mathbf{D N A})]$, which gives an approximate index of the proportion by weight of the component XP responsible for the excess phosphorus of the RNA fraction, drops rapidly in the penicillin-treated cultures (Table 1). Detailed studies on the XP component are in preparation for publication.

The changes in the shapes of the scattering spectra of the micrococci growing in the presence of penicillin are in agreement with the observations of Gardner (1940) and of Duguid (1946), who used visible light microscopy, and of Smiles, Welch \& Elford (1948), who used ultraviolet light and electron microscopy, of the swelling of the micrococci in the penicillin-containing media. The rate of change of the slope of the scattering spectra shows, however, that the swelling begins immediately after contact of the cells with the penicillin. This swelling accompanies the increase in $\% \mathrm{Nt}$ of the penicillin-treated cells just as it does in the normal cells. The rapid increase in the light-scattering coefficient and the decrease of suspension stability which follow the swelling of the cells show that substantial changes in the cell surfaces take place at an early stage in the action of penicillin. The inactivation of the glutamic acid accumulation mechanism in Gram-positive organisms may be associated with the changes in the cell 
surfaces, but the swelling effects which are known to occur in most organisms exposed to lethal concentrations of penicillin, whether or not they accumulate glutamic acid (Duguid, 1946; Dienes, 1949), suggest a more generalized disturbance of the osmotic and mechanical functions of the cell envelopes than that which would only involve amino-acid accumulation.

Following the preliminary description of our observations (Mitchell, 1949a), it was shown by McQuillen (1951) that a decrease in the negative $\zeta$ potential of the cell surfaces of $\boldsymbol{M}$. pyogenes var. aureus (strain Duncan) accompanies the decrease of suspension stability. According to McQuillen, the changes of $\zeta$ potential precede the other changes, but the evidence presented here is not in agreement with his view.

The later stages in the changes initiated by penicillin in $M$. pyogenes probably have little to do with the specific action of penicillin, but are simply typical of the autolytic processes which occur when growth has been stopped. The aim of this work has been to trace back the changes to the earliest one that we can identify. Our progress curves show, however, that the early disturbances follow one another with great rapidity, several of them apparently beginning immediately after contact of the penicillin with the cells. It is therefore impossible at present to decide which of the observed changes may be more closely connected with the initial disturbance. The evidence at present available suggests, however, that the disturbance of 'free nucleotide'/nucleic acid balance and of XP production, and the changes in the cell surfaces, all precede the disturbance to the glutamic acid accumulation mechanism in $M$. pyogenes.

We are indebted to Dr E. F. Gale for valuable advice and criticism, and to the Medical Research Council for personal grants.

\section{REFERENCES}

Borvin, A. (1948). Les acides nucléiques dans la constitution cytologique et dans la vie bactérienne. C.R. Soc. Biol., Paris, 142, 1258.

Caspersson, T. (1947). The relation between nucleic acid and protein synthesis. Symposia of the Society for Experimental Biology, no. 1, p. 127. Cambridge University Press.

Cooper, P. D. \& Rowley, D. (1949). Investigations with radioactive penicillin. Nature, Lond., 163, 480.

Drenes, L. (1949). The development of proteus cultures in the presence of penicillin. J. Bact. 57, 529.

Dufrenoy, J. \& Prate, R. (1947). Cytochemical mechanisms of penicillin action. III. Effect on reaction to Gram stain in Staphylococcus aureus. J. Bact. 54, 283.

Duguid, J. P. (1946). The sensitivity of bacteria to the action of penicillin. Edinb. med. J. 53, 401 .

Fiske, C. H. \& Subbarrow, Y. (1925). The colorimetric determination of phosphorus. J. biol. Chem. 66, 375.

Gale, E. F. (1948). The nitrogen metabolism of Gram-positive bacteria. Johns Hopk. Hosp. Bull. 83, 119.

Gale, E. F. \& Rodwell, A. W. (1949). The assimilation of amino-acids by bacteria. 7. The nature of resistance to penicillin in Staphylococcus aureus. J. gen. Microbiol. 3, 127.

Gale, E. F. \& TAYlor, E. S. (1947). The assimilation of amino-acids by bacteria. 5. The action of penicillin in preventing the assimilation of glutamic acid by Staphylococcus aureus. J. gen. Microbiol. 1, 314. 
Gardner, A. D. (1940). Morphological effects of penicillin on bacteria. Nature, Lond., 146, 837.

Gros, F. \& Macheboeuf, M.(1948). Recherches biochemiques sur le mode d'action de la penicilline sur un bactérie: Clostridium sporogenes. Ann. Inst. Pasteur, 74, 368.

Gros, F. \& Macheboeuf, M. (1949). Recherches biochemiques sur la penicilline et la streptomycine. 1st Int. Congr. Biochem. (Cambridge), Abstracts, p. 458.

Henrici, A. T. (1923). A statistical study of the form and growth of Bacterium coli. Proc. Soc. exp. Biol., N.Y., 21, 215.

Henry, H. \& Stacey, M. (1946). Histochemistry of the Gram staining reaction for micro-organisms. Proc. roy. Soc. B, 133, 391.

Hотснкiss, R. D. (1948). The quantitative separation of purines, pyrimidines and nucleosides by paper chromatography. J. biol. Chem. 175, 315.

KerR, S. E. \& Seraidarian, K. (1945). The separation of the purine nucleosides from free purines and the determination of the purine and ribose in these fractions. J. biol. Chem. 159, 211.

Krampitz, L. O. \& Werkman, C. H. (1947). On the mode of action of penicillin. Arch. Biochem. 12, 57.

LAMer, V. K. (1943). Progress report on 'Verification of Mie theory-calculations and measurements of light scattering by dielectric spherical particles'. U.S. Office of Scientific Research and Development. Report, no. 1857.

Lee, S. W., Foley, E. J. \& Epstein, J. A. (1944). Mode of action of penicillin. I. Bacterial growth and penicillin activity-Staphylococcus aureus F.D.A. J. Bact. 48, 393.

Maass, E. A. \& Johnson, M. J. (1949). Penicillin uptake by bacterial cells. J. Bact. $57,415$.

Matmgren, B. \& Hedén, C. (1947). Studies of the nucleotide metabolism of bacteria. IV. The nucleotide metabolism of Gram-positive bacteria. Acta path. microbiol. scand. 24, 472.

McQUILlen, K. (1951). The bacterial surface. III. Effect of penicillin on the electrophoretic mobility of Staphylococcus aureus. Biochim. Biophys. Acta, 6, 534.

Mrtcheld, P. (1949a). Some observations on the mode of action of penicillin. Nature, Lond., 164, 259.

Mrtcheld, P. (1949b). A new technique for stirred aerated culture. Nature, Lond., $164,846$.

Mrtchell, P. (1950a). Spectrophotometric estimation of nucleic acid in bacterial suspensions. J. gen. Microbiol. 4, 399.

Mrtchell, P. $(1950 \mathrm{~b})$. Nucleic acid synthesis and the bactericidal action of penicillin. Ph.D. Thesis, University of Cambridge.

Mitchell, P. \& Moyde, J. (1950). Occurrence of a phosphoric ester in certain bacteria : its relation to Gram staining and penicillin sensitivity. Nature, Lond., 166, 218.

Ploeser, J. M. T. \& Loring, H. S. (1949). The ultraviolet absorption spectra of the pyrimidine ribonucleosides and ribonucleotides. J. biol. Chem. 178, 431.

Schmidt, G. \& Thannhauser, S. J. (1945). A method for the determination of desoxyribonucleic acid, ribonucleic acid and phosphoproteins in animal tissues. J. biol. Chem. 161, 83.

Smiles, J., Welch, F. V. \& Elford, W. J. (1948). The influence of antibacterial substances on the interaction of bacteria and bacteriophages. 2. Optical studies of the penicillin effect. J. gen. Microbiol. 2, 220.

Stephenson, M. \& Moyle, J. (1949). Nucleic acid metabolism of Escherichia coli. Biochem. J. 45, vii.

Tulasne, R. \& Vendrely, R. (1948). Cytology of staphylococci before and after treatment with penicillin. Nature, Lond., 161, 316.

(Received 10 July 1950) 